\title{
Environmental enrichment reduces aggression of pearl cichlid, Geophagus brasiliensis, during resident-intruder interactions
}

\author{
Vivian Oliveira Kadry $^{1}$ and Rodrigo Egydio Barreto ${ }^{1,2}$
}

Among fishes, when residents and intruders fight, residents usually win, most likely because they value the residence more than intruders. We hypothesized that enriched environments increase the value of an area in dispute, causing a resident to more fiercely defend a resource-rich environment than a poor one. However, in the present study, intruder-resident tests with the pearl cichlid, Geophagus brasiliensis, showed environmental enrichment actually reduces aggression and can even lead to co-habitation without fighting. Additionally, in our experiments, the prior residence effect occurred irrespective of enrichment condition. Decreased visibility from increased habitat complexity reduces interactions between fish and consequently might explain the lower aggression observed herein.

Em lutas entre peixes residentes e intrusos, residentes geralmente vencem, provavelmente porque valorizam o território mais do que os intrusos. Nós aventamos a hipótese de que ambientes enriquecidos aumentam o valor da área em disputa, levando os residentes a defenderem mais violentamente ambientes enriquecidos de recursos do que ambientes empobrecidos, pois possuiriam mais motivação para mantê-lo. No entanto, no presente estudo, ao testarmos as interações entre intrusos e residentes em acarás, Geophagus brasiliensis, observamos que o enriquecimento ambiental reduz a agressividade e pode levar a cohabitação entre os peixes, sem luta. Adicionalmente, em nossos experimentos, o efeito da residência prévia ocorreu independente da condição de enriquecimento. A diminuição das interações entre os peixes e, consequentemente, a diminuição do nível de agressividade é aqui atribuída aos efeitos da diminuição da visibilidade entre os peixes devido ao aumento de complexidade do ambiente.

Key words: Fighting, Territoriality, Intruder-resident paradigm, Resource holding power, Cichlidae.

\section{Introduction}

Several animal species compete for environmental resources via aggressive interactions. When resources are limited, individuals that are more able to hold them tend to have short- and long-term benefits that maximize their fitness (Alcock, 2005). Resource retention may be linked to an animal's ability to maintain a territory (Ridley, 1995). Animals who adjust their aggressive behavior in defense of a specific area (Huntingford \& Turner, 1987) display territoriality, a phenomenon described in several taxa (Krasne et al., 1997; Bowen et al., 2008; Rosell et al., 2008; Morishita et al., 2009), including fish (Beaugrand \& Zayan, 1985; Barreto \& Volpato, 2006; Watanabe, 2008). In this context, a resident animal usually wins a fight with an intruder, probably because the resident animal values the territory more than an intruder (Enquist \& Leimar, 1987). Thus, the resident animal has greater odds of winning a contest because it fights more strongly for the territory (Smith \& Riechert, 1984) and/or uses its advantage of knowing the area (Beaugrand \& Zayan, 1985).

Competition for environmental resources might be also linked to a high investment in the habitat by the resident fish (Johnsson et al., 1999). In fact, resource-rich territories provide many benefits (e.g. shelters, food, nesting sites). Thus, it is plausible to conjecture that increased territory quality might motivate more the residents so that they likely win a contest. The increased motivation might occur in terms of increased aggressiveness (Elwood et al., 1998; Arnott \& Elwood, 2009). We expect that an increased number of attacks against an intruder might represent an advantage to the resident fish since this behavior may lead to a more rapid victory/ dominance in relation to a strategy of fewer attacks over a long period of time, in which greater energy loss and injury risk could occur.

${ }^{1}$ Campus Experimental do Litoral Paulista, UNESP, Unidade São Vicente. Praça Infante D. Henrique s/n, $11330-900$ São Vicente, SP, Brazil. rebarreto@yahoo.com

${ }^{2}$ Centro de Aquicultura da UNESP - CAUNESP and Research Center on Animal Welfare - RECAW. 
The Cichlid comprehends aggressive fish species (Turner, 1994; Barreto \& Volpato, 2006; Hirschenhauser et al., 2008), in which the effect of environmental enrichment described above we expect to occur. Nijman \& Heuts (2000) found the effect in the cichlid, Haplochromis burtoni, however without showing an increase in aggressive interaction frequency. In contrast, environmental enrichment actually decreases aggression in rainbow trout (Imre et al., 2002) and brown trout (Höjesjö et al., 2004), although these studies did not perform tests within an owner-intruder paradigm. Accordingly, in rainbow trout greater environmental complexity leads to smaller individual territories, while in brown trout the subordinate fish have more protected area in an enriched environment. Höjesjö et al. (2004) suggested that dominant fish likely had less visual perception of opponents from a higher amount of enrichment-produced physical barriers and, therefore, attacked less frequently than when the physical barriers were absent.

Based on these above statements, we suggest that, during a contest between resident and intruder fish, environmental enrichment can affect the "prior resident" effect, and consequently the level of aggression. We tested in controlled laboratory conditions the effects of territory enrichment, in a situation of prior residence, on fighting outcome and rate of aggressive interaction in the pearl cichlid, Geophagus brasiliensis (Quoy \& Gaimard). This species is a good fit for this study because resident individuals clearly exhibit territorial defensive behavior (Paraguassú et al., 2005).

\section{Material and Methods}

\section{Fish and holding conditions}

We used juvenile (sexually immature) wild caught pearl cichlid, Geophagus brasiliensis, a species from the Perciformes, Cichlidae family, as our stock population. The fish $(8.2 \pm 1.4 \mathrm{~cm})$ were held in two tanks (without enrichment) during 5 days of acclimation at a density of 20 fish/70-1 tank. We maintained water temperature at $28^{\circ} \mathrm{C}$, provided continuous aeration with an air stone, and used a $12 \mathrm{~L}: 12 \mathrm{D}$ photoperiod. We fed fish commercial dry flake ( $48 \%$ protein, Tetramin Tropical Flakes) two times each day, in a random schedule, and we removed leftover food and slowly changed at least 201 of de-chlorinated water each day to maintain good water quality.

\section{Experimental Strategy}

The experimental design consisted of testing fish pairs' intraspecific aggression in either an enriched or non-enriched environment. The previous residence paradigm was used to warrant aggression. As familiarity decreases aggression (Giaquinto \& Volpato, 1997), resident and intruder fish were chosen from different stock tanks. Basically, the resident fish was maintained into the aquarium (enriched or not) for $48 \mathrm{~h}$ and then a matched-size intruder was introduced and fish interactions recorded for $15 \mathrm{~min}$. For each condition, we evaluated 8-9 pairs of fish.

\section{Experimental procedures}

We used glass aquaria $(28 \times 20 \times 11 \mathrm{~cm}$; water volume $=61)$ in our experiments. We provided habitat enrichment into the tank by placing two river neutral pebbles (total weight $=200 \mathrm{~g}$ ) and one plastic kelp model, which are similar abiotic and biotic objects of pearl cichlid environment (Casatti \& Castro, 1998). These objects were placed as to not prevent accurate observation. We added no objects into the non-enriched tanks. These experimental conditions (enriched $v s$. bare tanks) were based on Imre et al. (2002) and Salvanes et al. (2007). Water temperature, aeration and photoperiod of experimental aquaria were similar to stoke-tank holding conditions.

Mean body lengths of the resident fish were not different between test conditions (mean $\pm \mathrm{SD}$; enriched condition, $7.8 \pm 1.5 \mathrm{~cm}$; non-enriched, $8.5 \pm 1.3 \mathrm{~cm} ; \mathrm{t}=0.98 ; \mathrm{p}=0.34$ unpaired Student's t-test). Mean body lengths of intruders were $7.8 \pm 1.2$ (enriched) and $8.5 \pm 1.4$ (non-enriched), and they were not significantly different from each other $(\mathrm{t}=1.01$; $\mathrm{p}=0.32$; unpaired Student's t-test). Mean percentage of size differences $( \pm \mathrm{SD})$ between individuals of each pair (resident + intruder) were similar between enriched and non-enriched conditions $(3.63 \pm 2.8 \%$ and $3.97 \pm 2.4 \%$, respectively; $t=0.27$; $\mathrm{p}=0.79$; unpaired Student's t-test). Furthermore, percentages of size differences were within a range (lower than $10 \%$ ) that avoids body size asymmetry effects on the outcome of another cichlid fish fights (Nijman \& Heuts, 2000).

We based observations of aggressive interactions (attacks) on the ethogram of G. brasiliensis aggressive behavior and quantified frequency of each of the follow aggressive unit: biting on anterior (head), tail fin, median or ventral area; lateral fight (a sudden slap between fish bodies) with fish oriented with the head in the same direction of the opponent or in opposite directions; chasing or mouth wrestling. Dominance hierarchy was identified by estimating the dominance index: $\mathrm{DI}=$ fish directed attacks/total number of aggressive interactions in the pair (Gómez-LaPlaza \& Morgan, 1993; Gonçalves-de-Freitas et al., 2008).

\section{Statistics}

A Shapiro-Wilk W test showed our data to be non-normal; therefore, we used a Mann-Whitney U test and Goodman Contrast test, between and within multinomial proportions (Goodman, 1965), to compare fish from enriched and nonenriched (control) conditions, and Wilcoxon test to compare resident and intruder values within each condition. We designated statistical significance at $\alpha=0.05$.

\section{Results}

While $100 \%(9: 9)$ of the pairs in the non-enriched condition fought, only $50 \%$ (4:8) of the pairs in the enriched condition did. These proportions are statistically different $\left(\mathrm{G}_{\text {observed }}=2.83>\mathrm{G}_{\text {expected }}=1.96 ; \mathrm{p}<0.05\right)$. Among the fighting pairs, the resident won the fight in about $78 \%(7: 2)$ and $75 \%$ (3:1) of the non-enriched and enriched conditions, respectively. These proportions are not statistically different 
$\left(\mathrm{G}_{\text {observed }}=0.11<\mathrm{G}_{\text {expected }}=1.96\right)$. Compared to enriched conditions, the frequency of aggressive interactions was higher in non-enriched conditions for both the resident $(\mathrm{Z}=$ $3.27, p<0.01)$ and intruder $(Z=2.17, p<0.05)$ (Fig. 1). In nonenriched conditions, the frequency of directed attacks by resident fish was statistically higher than attacks by intruders $(\mathrm{Z}=2.07, \mathrm{p}<0.05)$, but we found no differences in the enriched condition $(Z=1.10, p=0.27)$ (Fig. 1).

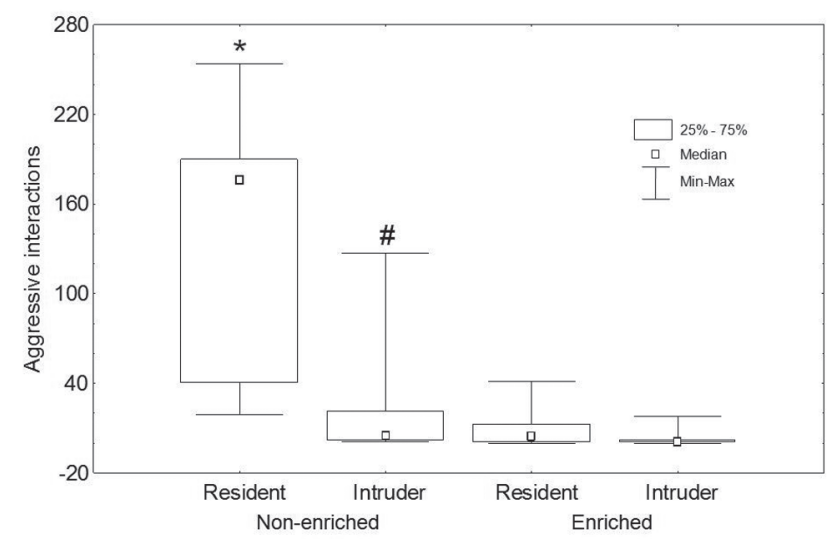

Fig. 1. Effect of environmental enrichment on aggressive interactions in pairs of pearl cichlid Geophagus brasiliensis. Aggression was studied in the resident fish's territory. The graphic shows median, quartiles, and minimum and maximum values. ${ }^{*}$ denotes statistical difference between values within a same enrichment condition ( $p<0.05$; Wilcoxon test) and between resident fish $(p<0.05$; Mann-Whitney $U$ test). \# denotes statistical difference between value for intruder fish $(\mathrm{p}<0.05$; Mann-Whitney U test).

\section{Discussion}

The resident-intruder paradigm has been described in several taxa (Krasne et al., 1997; Bowen et al., 2008; Rosell et al., 2008; Morishita et al., 2009), including fish (Beaugrand \& Zayan, 1985; Barreto \& Volpato, 2006; Watanabe, 2008). In this study, the pearl cichlids reinforce this paradigm irrespective of enrichment condition. The environmental enrichment condition, however, decreased aggression level (number of pairs engaged in fights and frequency of aggressive interactions).

Resident animals fight more strongly for territories that provide higher benefits of shelter, food and nest sites, to name a few, than for territories with less benefits (Alcock, 2005; Tizo-Pedroso \& Del-Claro, 2007; Contreras-Garduno et $a l ., 2008)$. Nijman \& Heuts (2000) showed that resident fish (including the cichlid, H. burtoni) win more fights, and become the dominant fish, more frequently when reared in an enriched environment, absent of greater aggressiveness. In this study, when pairs fought, the resident fish tended to be dominant at a statistically similar rate as the intruder, irrespective of environmental complexity. This indicates that enrichment does not increase the probability that a pearl cichlid will dominate and that the observed effect is most likely due to prior residence.

In this study, increased territory quality either induced less fighting or more co-habitation without fighting. Territorial enrichment with physical barriers such as kelp models and pebbles can cause fish to have smaller individual territories with less visibility of surrounding habitat (Imre et al., 2002; Höjesjö et al., 2004). We suggest that reduced visibility of territory could increase energetic costs for resident animals when they attack an intruder and, thus, fish in this situation would either decrease aggressive interactions or choose co-habitation as their best strategy. We believe that this idea is plausible because in another type of vertebrate (lizards, Anolis aeneus), when cover in complex habitats is available, the subordinate individuals retreat from interactions with dominants, lowering their likelihood of being chased away (Stamps, 1984). Environmental enrichment also reduces fitness of aggressive dominant brown trout in comparison to subordinates (Höjesjö et al., 2004). In the present study, the higher attacks of the intruder fish as compared with intruders into the enriched environment reinforce that lower probability of viewing the opponent should have mediated effects of environmental enrichment on aggressive interactions. This supports that enrichment in terms of a valuable resource for the resident fish was not a strong explanation in this study.

\section{Literature Cited}

Alcock, J. 2005. Animal Behavior: An Evolutionary Approach. Sunderland MA, Sinauer Associates, 564p.

Arnott, G. \& R. Elwood. 2009. Probing aggressive motivation in a cichlid fish. Biology Letters, 5: 762-764.

Barreto, R. E. \& G. L. Volpato. 2006. Stress responses of the fish Nile tilapia subjected to electroshock and social stressors. Brazilian Journal of Medical and Biological Research, 39: 1605-1612.

Beaugrand, J. P. \& R. Zayan. 1985. An experimental-model of aggressive dominance in Xiphophorus helleri (Pisces, Poeciliidae). Behavioural Processes, 10: 1-52.

Bowen, J. L., S. J. Mahony, A. C. Mason \& J. E. Yack. 2008. Vibration-mediated territoriality in the warty birch caterpillar Drepana bilineata. Physiological Entomology, 33: 238-250.

Casatti, L. \& R. M. C. Castro. 1998. A fish community of the São Francisco River headwaters riffles, southeastern Brazil. Ichthyological Exploration of Freshwaters, 9: 229-242.

Contreras-Garduno, J., B. A. Buzatto, M. A. Serrano-Meneses, K. Najera-Cordero \& A. Cordoba-Aguilar. 2008. The size of the red wing spot of the American rubyspot as a heightened condition-dependent ornament. Behavioral Ecology, 19: 724732.

Elwood, R. W., K. E. Wood, M. B. Gallagher \& J. T. A. Dick. 1998. Probing motivational state during agonistic encounters in animals. Nature, 393: 66-68.

Enquist, M. \& O. Leimar. 1987. Evolution of fighting behavior the effect of variation in resource value. Journal of Theoretical Biology, 127: 187-205. 
Giaquinto, P. C. \& G. L. Volpato. 1997. Chemical communication, aggression, and conspecific recognition in the fish Nile tilapia. Physiology \& Behavior, 62: 1333-1338.

Gómez-LaPlaza, L. M. \& E. Morgan. 1993. Social-isolation, aggression, and dominance in attacks in juvenile angelfish, Pterophyllum scalare. Aggressive Behavior, 19: 213-222.

Gonçalves-de-Freitas, E., F. B. Teresa, F. S. Gomes \& P. C. Giaquinto. 2008. Effect of water renewal on dominance hierarchy of juvenile Nile tilapia. Applied Animal Behaviour Science, 112: 187-195.

Goodman, L. A. 1965. On simultaneous confidence interval for multinomial proportions. Technometrics, 7: 247-254.

Hirschenhauser, K., A. V. M. Canario, A. F. H. Ros, M. Taborsky \& R. F. Oliveira. 2008. Social context may affect urinary excretion of 11ketotestosterone in African cichlids. Behaviour, 145: 1367-1388.

Höjesjö, J., J. Johnsson \& T. Bohlin. 2004. Habitat complexity reduces the growth of aggressive and dominant brown trout (Salmo trutta) relative to subordinates. Behavioral Ecology and Sociobiology, 56: 286-289.

Huntingford, F. A. \& A. K. Turner. 1987. Animal Conflict. New York, Chapman and Hall, 448p.

Imre, I., J. W. A. Grant \& E. R. Keeley. 2002. The effect of visual isolation on territory size and population density of juvenile rainbow trout (Oncorhynchus mykiss). Canadian Journal of Fisheries and Aquatic Sciences, 59: 303-309.

Johnsson, J. I., F. Noebbelin \& T. Bohlin. 1999. Territorial competition among wild brown trout fry: effects of ownership and body size. Journal of Fish Biology, 54: 469-472.

Krasne, F. B., A. Shamsian \& R. Kulkami. 1997. Altered excitability of the crayfish lateral giant escape reflex during agonistic encounters. Journal of Neuroscience, 17: 709-716.

Morishita, V. R., F. S. C. Buchmann, R. A. Christofoletti, G. L. Volpato \& R. E. Barreto. 2009. Prior residence and body size influence interactions between black sea urchins. Behavioural Processes, 80: 191-195.
Nijman, V. \& B. A. Heuts. 2000. Effect of environmental enrichment upon resource holding power in fish in prior residence situations. Behavioural Processes, 49: 77-83.

Paraguassú, A. R., D. R. Alves \& J. L. Luquel. 2005. Metazoários parasitos do acará, Geophagus brasiliensis (Quoy \& Gaimard, 1824) (Osteichthyes: Cichlidae) do Reservatório de Lajes, do Estado do Rio de Janeiro, Brasil. Revista Brasileira de Parasitologia Veterinária, 14: 35-39.

Ridley, M. 1995. Animal Behavior: an introduction to behavioral mechanisms, development and ecology. London, Blackwell Science, $276 \mathrm{p}$.

Rosell, F., G. Gundersen \& J. F. Le Galliard. 2008. Territory ownership and familiarity status affect how much male root voles (Microtus oeconomus) invest in territory defense. Behavioral Ecology and Sociobiology, 62: 1559-1568.

Salvanes, A. G. V., O. Moberg \& V. A. Braithwaite. 2007. Effects of early experience on group behaviour in fish. Animal Behaviour, 74: 805-811.

Smith, J. M. \& S. E. Riechert. 1984. A conflicting-tendency model of spider agonistic behavior - hybrid-pure population line comparisons. Animal Behaviour, 32: 564-578.

Stamps, J. A. 1984. Growth costs of territorial overlap - experiments with juvenile lizards (Anolis aeneus). Behavioral Ecology and Sociobiology, 15: 115-119.

Tizo-Pedroso, E. \& K. Del-Claro. 2007. Cooperation in the neotropical pseudoscorpion, Paratemnoides nidificator (Balzan, 1888): feeding and dispersal behavior. Insectes Sociaux, 54: 124-131.

Turner, G. F. 1994. The fighting tactics of male mouthbrooding cichlids - the effects of size and residency. Animal Behaviour, 47: 655-662.

Watanabe, K. 2008. Diel activity and reproductive territory of the Japanese bagrid catfish, Pseudobagrus ichikawai. Environmental Biology of Fishes, 81: 77-86.

Accepted January 11, 2010

Published June 25, 2010 